\title{
Treatment of By-Products Generated from Anaerobic Digestion of Municipal Solid Waste
}

\author{
Przemysław Seruga $^{1}$ (D) $\cdot$ Małgorzata Krzywonos $^{1} \cdot$ Marta Wilk $^{1}$
}

Received: 22 May 2019 / Accepted: 23 September 2019 / Published online: 1 October 2019

(c) The Author(s) 2019

\begin{abstract}
Purpose This study aimed to examine the possibilities of the treatment of the by-products generated in the anaerobic digestion (AD) of the organic fraction of municipal solid waste (OFMSW): oxygen stabilization (composting) of the solid digestate and pretreatment with air stripping of the effluents (liquid digestate and leachate from maturation field and reactors from composting).

Methods Oxygen stabilization (OS) was performed in full-scale in a mechanical-biological treatment (MBT) plant using three different methods, using an open field or enclosed box reactor with aeration. The ammonia stripping was performed in a pilot-scale installation using effluents from $\mathrm{AD}$ (liquid digestate) and OS (leachate from maturation field and reactors). Results The lowest self-heating possibility after the OS was recorded at $28.5^{\circ} \mathrm{C}$, which proves that the most stabilized was the sample after processing with structuring material addition. Due to air stripping, the highest efficiency of ammonium ions removal was noted at the level of $50.6 \%$, with an initial $\mathrm{pH}$ value of 10.5 , after $12 \mathrm{~h}$. Among the examined factors $\mathrm{pH}$ value was found to be significant [the determination coefficient $\left(\mathrm{R}^{2}\right)$ of 0.93 ].

Conclusions The oxygen stabilization of the digestate requires the structuring material addition before being placed in the reactor with aeration. The inert fraction from the ballistic separation of the OFMSW can be an interesting solution, as required structuring material. Air stripping as the effluents pre-treatment step can meet the MBT plants expectations.
\end{abstract}

\section{Graphic Abstract}

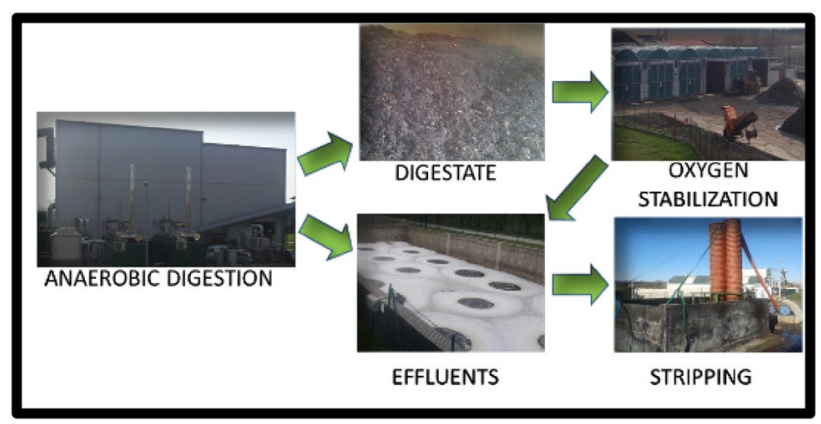

Keywords Bioenergy $\cdot$ Municipal waste $\cdot$ Digestate $\cdot$ Effluents $\cdot$ Stripping $\cdot$ Fermentation

\section{Statement of Novelty}

Przemysław Seruga

przemyslaw.seruga@ue.wroc.pl

1 Department of Bioprocess Engineering, Wrocław University of Economics, Komandorska 118/120, 53-345 Wrocław, Poland
Problems concerning material and energy recovery from waste are currently major issues in the waste management, considering sustainability, circular economy and recycling. Anaerobic digestion (AD) is the most promising process 
for the treatment of organic waste allowing for the biogas recovery.

However, attention should also be paid to the process byproducts: the digestate and the effluents. The examined literature is scarce in $\mathrm{AD}$ by-products treatment methods, especially in full scale. The conducted usage of the inert fraction from the ballistic separation of the waste developed in this work, allows meeting the minimum requirements for its processing. Air stripping as the effluents (obtained from AD (liquid digestate) and oxygen stabilization (leachate from open field and reactors) pre-treatment step can also meet the waste treatment plants expectations. These novel solutions could be used for enhanced the treatment processes.

\section{Introduction}

Significant growth in the importance of material and energy recovery from waste has been noticeable over the last few decades [1,2]. The current policy is focused on the reduction of primary resources exploitation based on circular management to minimize landfilling [3-5].

Source-segregation is considered as a solution in a nonlandfill waste management system, but plenty of environmental, economic and social factors, together with changing governance and political systems have an impact on the final effect. Source-segregation of waste may be intractable within high density urban communities $[6,7]$. Among municipal solid wastes (MSW) collected globally, only 15\% is recycled. The landfilling remains main disposal route, regardless of country income [8].

Due to this, the number of industrial scale facilities aimed at recovery of valued materials and energy from nonsegregated MSW has increased [9]. Mechanical-biological treatment (MBT) includes the stabilization of biodegradable fractions through composting or anaerobic digestion (AD), as a stage within a sorting and separation process $[1,9]$.

Over recent years, anaerobic digestion of the organic fraction of municipal solid waste (OFMSW) has been used widely as a form of energy recovery in the form of biogas and many researchers, businesses and government agencies are working to improve the process [10]. It can be seen that $\mathrm{AD}$ is the most promising and sustainable process for the treatment of organic waste and it is an environmentally friendly method for MSW management [11-13]. However, attention should also be paid to the $\mathrm{AD}$ process by-products: the digestate (semi-solid residue) and the effluents (together liquid digestate as well as the leachate from composting reactors and maturation field).

According to the MBT pathway, AD should be followed by composting. The composting is a natural process conducted in aerobic conditions, leading to partial mineralization and humification of biomass. During the mineralization, the organic substance is transformed into mineral compounds and the oxidation of organic matter to carbon dioxide, water, nitrates, phosphates and sulfates occurs. The humification process involves converting organic compounds into humus [14-16]. The decomposition of organic matter is influenced by several factors that can be divided into two general groups: variables that determine the concentrations of biodegradable compounds and affect the size of microbial populations and their activity, and factors that directly control the kinetics of the reaction itself, such as: temperature, oxygen ratio and humidity [17]. Regarding non-segregated MSW, the composting is determined as the oxygen stabilization and can be defined as the process of aerobic thermophilic degradation of organic matter by a mixed population of microorganisms that leads to obtaining a stabilized, deodorized, hygienic product before landfilling $[18,19]$. The oxygen stabilization has been widely studied [20-23], but only a few studies have focused on full-scale stabilization [24-26]. Furthermore, the available literature regarding the stabilization of the digestate is scarce.

Apart from the digestate, effluents should also be considered as a by-product, which requires proper management. In biological waste treatment processes the effluents from $\mathrm{AD}$ (liquid digestate) together with leachate from OS, with high organic and nitrogen loads are generated. In industrial facilities two management pathways can be found: self-treatment or transfer to external wastewater treatment plants (WWTP) $[27,28]$. For WWTP, the main problem is an enormous load of ammonium ions [29]. Its concentration should be reduced in pre-treatment processes carried out in situ. Furthermore, due to the high variability of the volume and composition of the effluents treatment is found to be difficult [30,31].

The effluent treatment processes are based on the pollutant elimination (anaerobic and aerobic biological processes, adsorption, chemical oxidation or combustion) $[32,33]$ or concentration (flocculation, precipitation, ultrafiltration, nanofiltration, reverse osmosis and evaporation) $[34,35]$. Of those mentioned, air stripping is considered as the simplest method [36]. It mainly requires $\mathrm{pH}$ and temperature control.

Under stable conditions the stripping process is relatively independent of the suspension content and the presence of other ions. However, raising the $\mathrm{pH}$ value with lime to 10.5-11.5 results in the deposition of calcium carbonate. Nevertheless, stripping has been successfully used for the treatment of wastewater with a large load of ammonium ions, both for leachate from landfills and oil refineries, or effluents from the anaerobic digestion of pig, cattle and chicken manures [29, 37].

This study aimed to examine the possibilities for the treatment of the by-products generated in anaerobic digestion of the organic fraction of municipal solid waste: oxygen stabilization of the digestate and pretreatment with air stripping of the effluents. 


\section{Materials and Methods}

\section{The Digestate}

The research was performed at an MBT Plant located in the Lower Silesia Region, Poland. The digestate was obtained after anaerobic digestion of the organic fraction of municipal solid waste (OFMSW) in thermophilic conditions. It was characterized by: dry matter content at the level of $48 \%$, cumulative $\mathrm{O}_{2}$ consumption after four days (AT4) of $4.5 \mathrm{O}_{2} / \mathrm{g}$ (based on dry matter), loss on ignition (LOI) amounting to $38.2 \%$, total organic carbon at the level of $23.3 \%$ and density of $1.1 \mathrm{~kg} / \mathrm{L}$.

\section{The Effluents}

The effluents from both biological treatment processes (AD and OS) performed in an MBT plant were collected in a $650 \mathrm{~m}^{3}$ tank and used in research. Its characteristics can be found in Table 1.

\section{Oxygen Stabilization Facility and Conditions}

Oxygen stabilization was performed, using three methods, lasting two weeks, in full-scale in an MBT plant. In the first one, the digestate was placed on an open field and mechanically turned once a week. In the second and third, the digestate was kept in an enclosed box reactor (pile size $21.5 \mathrm{~m} \times 7.5 \mathrm{~m} \times 2.0 \mathrm{~m}$ ) with irrigation and positive aeration by a blower with air capacity $60.5 \mathrm{~m}^{3} / \mathrm{min}$. The temperature was measured using stainless temperature probes $2 \mathrm{~m}$ long. The probe had three sensors located at intervals $20 \mathrm{~cm}$ apart, starting from the tip of the probe. After one week, the piles were mechanically turned. However, in the third trial a $30 \%$ addition of structuring material (inert fraction after OFMSW ballistic separation before AD) was added.

Table 1 The effluents characterization

\begin{tabular}{lrc}
\hline Parameter & \multicolumn{1}{l}{ Result } & Unit \\
\hline pH & $7.8 \pm 0.3$ & {$[-]$} \\
Chemical oxygen demand (COD) & $18.7 \pm 1.3$ & {$[\mathrm{~g} / \mathrm{L}]$} \\
Biological oxygen demand (BOD) & $6.0 \pm 0.5$ & {$[\mathrm{~g} / \mathrm{L}]$} \\
Ammonium nitrogen & $0.8 \pm 0.2$ & {$[\mathrm{~g} / \mathrm{L}]$} \\
Total nitrogen & $1.1 \pm 0.3$ & {$[\mathrm{~g} / \mathrm{L}]$} \\
Total organic carbon (TOC) & $3.1 \pm 0.2$ & {$[\mathrm{~g} / \mathrm{L}]$} \\
Total suspended solids (TSS) & $0.6 \pm 0.2$ & {$[\mathrm{~g} / \mathrm{L}]$} \\
$\mathrm{Cl}^{-}$ & $1.3 \pm 0.2$ & {$[\mathrm{~g} / \mathrm{L}]$} \\
\hline
\end{tabular}

\section{Air Stripping Facility and Conditions}

The ammonia stripping was performed in a pilot scale installation prepared in an MBT plant, which consisted of a tank $\left(10 \mathrm{~m}^{3}\right)$ in which two pipes (height $4 \mathrm{~m}$, diameter $0.9 \mathrm{~m}$ ) filled with Bialecki rings were provided. The sewage from the tank was recirculated to the tower until the process was completed. The air was supplied in the countercurrent flow. The initial $\mathrm{pH}$ adjustment was made using a $50 \% \mathrm{NaOH}$ solution. The effluents temperature in the tank oscillated around $17^{\circ} \mathrm{C}$.

\section{Analytical Methods}

Stabilization of the material after the oxygen process was determined using a self-heating test. Dewar flasks $(2.0 \mathrm{~L}$ capacity; $100 \mathrm{~mm}$ internal diameter) equipped with electronic memory thermometers were used as the Dewar Kit [38]. Determination of moisture was done using a squeeze test [39]. If the material was found to be too dry, water was added. If it was too wet, it had to be dried overnight by spreading on a flat, clean surface. After confirmation of the optimal moisture level for the test, the Dewar flask was filled with material chilled to room temperature and the thermometer probe was inserted. The internal temperature was measured at $2 \mathrm{~h}$ intervals throughout the experiment.

The dry mass and dry organic mass were determined according to standard methods [40].

The cumulative $\mathrm{O}_{2}$ consumption after four days (AT4) parameter was determined following the standard: PB-ZP4:2013 ed. 1 from 25/01/2013, and the total organic carbon by PN-EN 13,137: 2004.

The content of ammonium ions in the wastewater was determined using an ammonium ion-selective electrode (DETEKTOR) with a silver-chloride reference electrode (DETEKTOR) and an ionometer (ELMETRON CPI-505). Spectrophotometrically cuvette tests (Hach-Lange LCK 302) were also performed.

\section{Calculation and Statistical Methods}

The ammonium ions concentration decrease for stripping was calculated using the formula:

$\Delta \mathrm{C}=\left[\left(\mathrm{C}_{0}-\mathrm{C}_{\mathrm{k}}\right) / \mathrm{C}_{0}\right] \times 100 \%$, where $\Delta \mathrm{C}$ is the ions removal [\%], $\mathrm{C}_{0}$ is the ions concentration at the beginning $[\mathrm{mg} / \mathrm{L}]$ and $\mathrm{C}_{\mathrm{k}}$ is the ions concentration at the end $[\mathrm{mg} / \mathrm{L}]$.

To assess how the initial $\mathrm{pH}$ value, process time, and effluents flow rate influence the ammonium ions removal the fractional plan [3(3-1)] for three factors on three levels with two replicates was generated using Design of Experiments Module of STATISTICA version 10 (StatSoft, Inc., 2011, USA) (Table 2) was used. The initial $\mathrm{pH}$ value $\left(\mathrm{X}_{1}\right)$ was at the level of $8.5,9.5$ or 10.5 . The effluents flow rate $\left(\mathrm{X}_{2}\right)$ was 
Table 2 The experimental design matrix with coded values and factors levels

\begin{tabular}{llll}
\hline Run & X1 pH value & X2 effluents flow rate & $\begin{array}{c}\text { X3 time of the } \\
\text { experiment }\end{array}$ \\
\hline 1 & -1 & -1 & -1 \\
2 & -1 & 0 & 0 \\
3 & -1 & 1 & 1 \\
4 & 0 & -1 & 0 \\
5 & 0 & 0 & -1 \\
6 & 0 & 1 & -1 \\
7 & 1 & -1 & 1 \\
8 & 1 & 0 & Max. value $(1)$ \\
9 & 1 & 1 & 10.5 \\
\hline Factor & Min. value $(-1)$ & Mid. value $(0)$ & 1.0 \\
\hline pH value & 8.5 & 9.5 & 24.0 \\
Effluents valve position & 0.5 & 0.75 & 18.0 \\
Time & 12.0 & & \\
\hline
\end{tabular}

set up by the valve opening position $(1.0,0.75,0.5)$. The process was carried out for 12,18 or $24 \mathrm{~h}\left(\mathrm{X}_{3}\right)$. The experimental results were analyzed and interpreted using STATISTICA StatSoft ver. 10. All statistical tests were evaluated at the $95 \%$ confidence level.

\section{Results and Discussion}

The aerobic stabilization full- scale process control is based on the regulation of variables such as supplied air and water, the frequency of turning and process time [24, 26]. The frequency of the mechanical turning affecting the organic matter decomposition and the compost quality [41, 42]. Getahun et al. [41] confirmed that the rate of organic matter decomposition increased with the increase in the frequency of turning. Besides, the shortest stabilization time was observed for the highest turning frequency. The experiments were conducted using a specially prepared mixture of biodegradable municipal solid waste in three containers with different turning frequency [41].

Mechanical turning, especially in full-scale, generates costs and requires proper management. In the case of an intensive stabilization process performed in bioreactors with enforced aeration, the frequency of turning is not significant. The results of this study confirm this statement. The aeration, in addition to providing oxygen and preventing anaerobic zones, ensures cooling and moisture reception in the pile. However, it should be noted that for processes carried out in an open field, mechanical turning is the only way to aerate the inside of the pile and to maintain process correctly.

The self-heating tests results were presented in the Fig. 1. In the present study the same effect was obtained when the digestate was on an open field mechanical turned once a

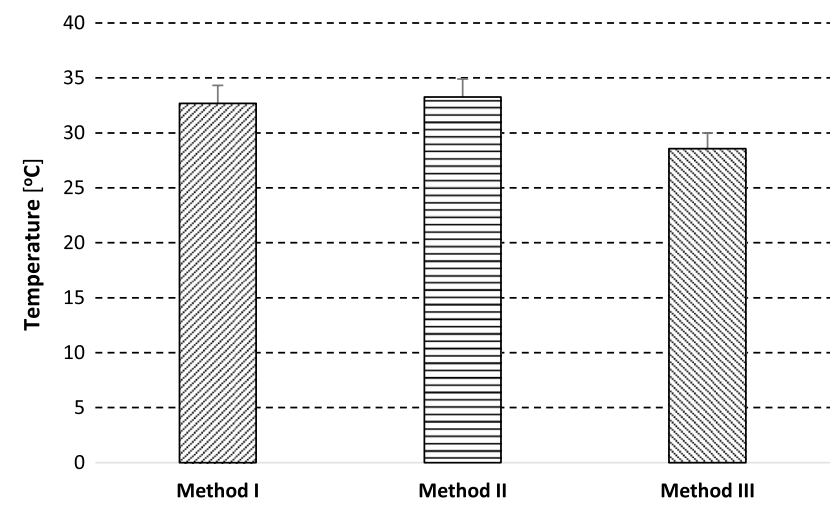

Fig. 1 The stabilized digestate self-heating test results for each of examined method: I-the OS on an open field; II-the OS in the reactor; III- the OS in the reactor with structuring material addition

week and when the digestate was in the bioreactor with irrigation and positive aeration. The temperature of the material determined in the Dewar's vessel was at the level at 32.7 and $33.2{ }^{\circ} \mathrm{C}$, respectively (Fig. 1). The insufficient air flow in the reactor might be a reason for that, because due to aerated pile the process should be more efficient. The digestate high density (over $1 \mathrm{~kg} / \mathrm{L}$ ) collectively with moisture content (over 50\%) contributed to the composting inefficiency.

The aeration of the stabilized pile must ensure sufficient air for the aerobic degradation of the organic matter. The enforced aeration affects the oxygen concentration inside the pile, cooling the material, destroying pathogens and the decomposition of organic matter [43]. The importance of the aeration was also confirmed in the present studies. Moisture also affects the organic matter decomposition process and the oxygen demand, as well. The rate of oxygen uptake increases linearly with increasing moisture and reaches a 
maximal value of $50-70 \%$, after which it begins to decrease, while below $20 \%$ there is deficient biological activity [44].

Digestate stabilization was achieved in the bioreactor with enforced aeration. However, it should be noted that the proper porosity of the stabilized material is required to ensure the air flow inside the pile. The digestate is characterized by about $50 \%$ moisture content with its density at $1.1 \mathrm{~kg} / \mathrm{L}$ which can block the possibility of the air flow inside the pile. The lowest self- heating possibility was recorded at $28.5{ }^{\circ} \mathrm{C}$ (Fig. 1), in accordance to the trial in which, before placing the material in the bioreactor, the $30 \%$ by mass of structuring material (inert fraction after OFMSW ballistic separation before AD) was added to the digestate. Stabilization on an open field without enforced aeration resulted in a similar effect as the process in a bioreactor with digestate without structuring material, which confirms the above statements. The temperature of the material determined in the Dewar's vessel was at the level at 32.7 and $33.2^{\circ} \mathrm{C}$, respectively (Fig. 1). Based on that, it can be classified as a still maturing compost, which according to the Rottegrad index equals IV [39, 45]. However, it should be noted that the structuring material addition, which reduced the density of the stabilized material, affected process efficiency. Fulfilling the aeration role, with the moisture remaining at $40 \%$, resulting in self-heating possibility decrease to $28.5^{\circ} \mathrm{C}$, which proves the compost maturity and the stability based on the Rottegrad index V [39, 45].

The temperature variation measured during digestate OS with structuring material addition in the reactor is shown in Fig. 2. It can be seen that the temperature inside the pile decreased with time, which indicates the organic matter decomposition. The mechanical turning of the pile on day 7 loosened the material, enabled access of microorganisms to further resources of organic matter, which resulted in an increase in their activity, illustrated by a temporary increase in the temperature of the pile. Compared to OS results obtained for Method II it can be found that due to microorganism activity crucial was the proper porosity of the stabilized material which ensures the airflow inside the pile.

Figure 3 shows the abatement of ammonium ions content after the air stripping process. The highest efficiency was noted at the level of $50.6 \%$ in the run $\# 8$, with the initial $\mathrm{pH}$ value of 10.5, after $12 \mathrm{~h}$ (Fig. 3). The lowest was observed in runs $1-3$, which were characterized by the lowest initial $\mathrm{pH}$ values. Based on ammonium ions removal results statistical analysis was done and the results are presented in Table 3. Among examined factors, $\mathrm{pH}$-value was found to be significant. The determination coefficient (R2) of 0.93 (which means that the model explains $93 \%$ of the total variation) suggests an adequate representation of the process model and a good correlation between the experimental and predicted values $[46,47]$.

Ipekoglu and Talinli [48] attempted to remove ammonium ions from human urine samples in a reactor constructed of a $1 \mathrm{~L}$ flask with a perforated tube inserted into it for aeration. With a constant flow of the introduced air $\left(0.12 \mathrm{~m}^{3} / \mathrm{h}\right)$, an increase in the efficiency of the process was observed along with an increase in the $\mathrm{pH}$ value. For the initial $\mathrm{pH}$ at the level of 11 , the ammonium ions content removal of $82 \%$ was achieved within $19 \mathrm{~h}$. Raising the $\mathrm{pH}$ to 12 resulted in a shortening of the time needed to achieve the same result of up to $8 \mathrm{~h}$. Further raising of the $\mathrm{pH}$ value, up to $13.5 \mathrm{did}$ not speed up the process anymore. The increase in aeration also resulted in a positive effect on the process efficiency. With an air flow of $0.12 \mathrm{~m}^{3} / \mathrm{h}$, the $86 \%$ reduction in ammonium concentration was noted after $9 \mathrm{~h}$. For a flow rate of

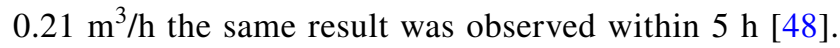
In the present study, aeration was maintained at the same
Fig. 2 The temperature of material stabilized in the reactor with structuring material addition (method III)

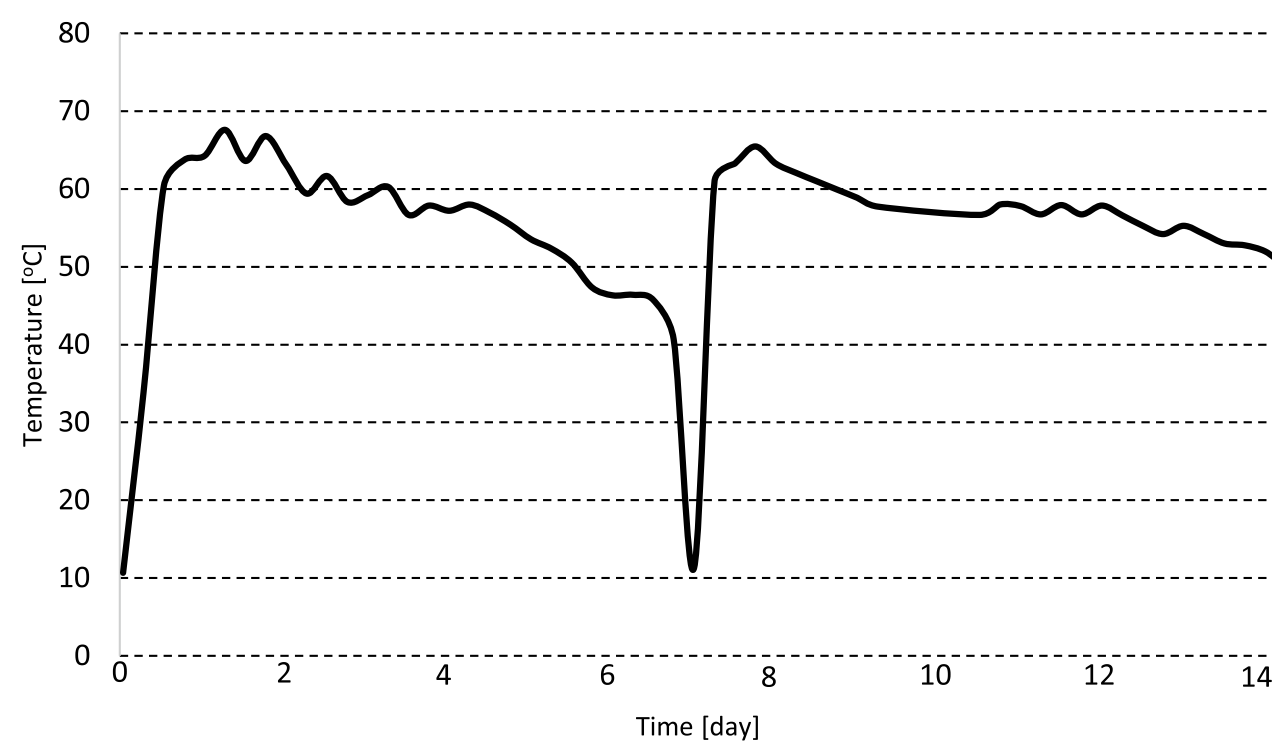


Fig. 3 The ammonium ions concentration decrease after stripping

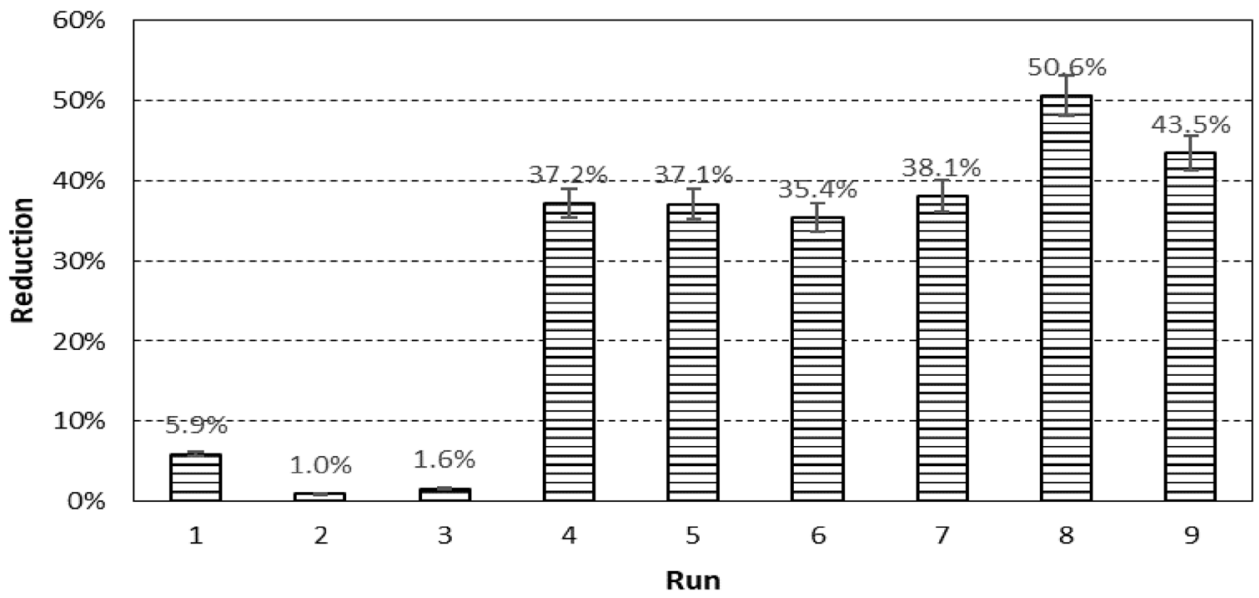

Table 3 Statistical analysis results

\begin{tabular}{lrll}
\hline Factor & Effect & P value & Significance* \\
\hline pH value & 0.206 & 0.003 & $"+"$ \\
Effluents flow-rate & -0.001 & 0.980 & $"-"$ \\
Time & -0.017 & 0.665 & $"-"$ \\
\hline
\end{tabular}

$*$ Significant at $5 \%$, standard error $=0.0375, \mathrm{R}^{2}=0.93$

level, but the effluents flow was adjusted. However, based on statistical analysis (Table. 3), it can be found that this factor was insignificant in the examined range. The initial $\mathrm{pH}$ value was considered to be influencing the process. This statement can be confirmed by other researchers [36, 49]. $\mathrm{CaO}$ and $\mathrm{NaOH}$ are the most commonly used reagents in the industry for adjusting the $\mathrm{pH}$ value. Lime is mainly used due to economic factors. However, correction with lime requires larger quantities and more extended response time compared to $\mathrm{NaOH}$. Lime also causes precipitation and formation of insoluble calcium salts, causing operational difficulties [39].

Limoli et al. [39] performed the ammonium ions removal research using the leachate from an agricultural biogas plant. The concentration of total nitrogen was in the range of 4-5 g/L. The mentioned authors compared the effect of using $\mathrm{CaO}$ and $\mathrm{NaOH}$ for $\mathrm{pH}$ correction on the process. Both allowed the $\mathrm{pH}$ to reach the level of 12 and remove the nitrogen content by about $51 \%$. However, due to the ease of use, reaction rate and lack of deposits, sodium hydroxide was considered to be a better reagent. Considering the mentioned disadvantages and the suspensions content in the examined effluents, $\mathrm{NaOH}$ was used in the present study. Due to research conditions, despite the potential benefits of the process conducting at a $\mathrm{pH}$ of 12 , maximal examined $\mathrm{pH}$ value was at the level of 10.5. Nevertheless, a more than 50\% removal of the ammonium ions concentration was achieved.

Liu et al. [37] examined the effect of lime dose, gas flow rate and gas/liquid ratio on the ammonium ions removal.
An increase in process efficiency was observed along with the lime addition, which led to a higher $\mathrm{pH}$ value. However, this increase was not proportional. Furthermore, an increase in the air flow resulted in a process efficiency reduction. The cited authors defined the increasing production of foam and the formation of calcium hydroxide as a cause of this observation [37].

Considering the mentioned statements, comparing advantages and disadvantages of using $\mathrm{CaO}$ and $\mathrm{NaOH}$ for $\mathrm{pH}$ correction on the process, to avoid foam production and precipitation of sewage sludge leading to operational problems, a $50 \%$ solution of sodium hydroxide was used in the present study.

\section{Conclusion}

The oxygen stabilization (OS) of the digestate from anaerobic digestion of the organic fraction of municipal solid waste (OFMSW) in thermophilic conditions is, due to its characteristics: high density (over $1 \mathrm{~kg} / \mathrm{L}$ ) jointly with humidity (over 50\%) challenging to perform. It requires the structuring material addition before being placed in the reactor with aeration. The method of the digestate OS, based on the usage of the inert fraction from the ballistic separation of the OFMSW developed in this work, could be an interesting solution. The $30 \%$ by mass of structuring material addition allowed to meet the minimum requirements for its processing in aerobic conditions (composting) before depositing in a landfill in MBT plant, resulting in self-heating possibility decrease to $28.5{ }^{\circ} \mathrm{C}$, which proves the compost maturity and the stability based on the Rottegrad index V. Air stripping as the effluents pre-treatment step can meet the MBT plants expectations, allowing to the ammonium ions concentration decrease by $50.6 \%$ with an initial $\mathrm{pH}$-value correction to 10.5. The complementation of the effluents management procedure with the stripping tower allowed the reaching of 
an ammonium ions content level accepted by a municipal wastewater treatment plant.

Acknowledgements This research was supported by Zakład Gospodarki Odpadami GAĆ in Poland.

Open Access This article is distributed under the terms of the Creative Commons Attribution 4.0 International License (http://creativecommons.org/licenses/by/4.0/), which permits unrestricted use, distribution, and reproduction in any medium, provided you give appropriate credit to the original author(s) and the source, provide a link to the Creative Commons license, and indicate if changes were made.

\section{References}

1. Blake, L.I., Halim, F.A., Gray, C., Mair, R., Manning, D.A.C., Sallis, P., Hutchinson, H., Gray, N.D.: Evaluating an anaerobic digestion (AD) feedstock derived from a novel non-source segregated municipal solid waste (MSW) product. Waste Manag. 59, 149-159 (2017). https://doi.org/10.1016/j.wasman.2016.10.031

2. Cremiato R., Laura M., Tagliaferri C., Zaccariello L., Lettieri P., Environmental impact of municipal solid waste management using life cycle assessment: the effect of anaerobic digestion, materials recovery and secondary fuels production. Renew. Energy, 124, 1-9 (2017). https://doi.org/10.1016/j.renene.2017.06.033

3. Edwards, J., Othman, M., Crossin, E., Burn, S.: Life cycle assessment to compare the environmental impact of seven contemporary food waste management systems. Bioresour. Technol. 248, 156-173 (2018). https://doi.org/10.1016/j.biortech.2017.06.070

4. Fernández-González, J.M., Grindlay, A.L., Serrano-Bernardo, F., Rodríguez-Rojas, M.I., Zamorano, M.: Economic and environmental review of waste-to-energy systems for municipal solid waste management in medium and small municipalities. Waste Manag. 67, 360-374 (2017). https://doi.org/10.1016/j.wasma n.2017.05.003

5. Moretti, M., Van Dael, M., Malina, R., Van Passel, S.: Environmental assessment of waste feedstock mono-dimensional and biore fi nery systems : combining manure co-digestion and municipal waste anaerobic digestion. J. Clean. Prod. 171, 954-961 (2018). https://doi.org/10.1016/j.jclepro.2017.10.097

6. Di Maria, F., Micale, C., Morettini, E.: Impact of the pre-collection phase at different intensities of source segregation of biowaste : an Italian case study. Waste Manag. 53, 12-21 (2016). https://doi.org/10.1016/j.wasman.2016.04.026

7. Rispo, A., Williams, I.D., Shaw, P.J.: Source segregation and food waste prevention activities in high-density households in a deprived urban area. Waste Manag. 44, 15-27 (2015). https://doi. org/10.1016/j.wasman.2015.04.010

8. Zaman, A.U.: A comprehensive study of the environmental and economic bene fits of resource recovery from global waste management systems. J. Clean. Prod. 124, 41-50 (2016). https://doi. org/10.1016/j.jclepro.2016.02.086

9. Montejo C., Tonini D., del Carmen Márquez M., Astrup T.F., Mechanical - biological treatment: Performance and potentials . An LCA of 8 MBT plants including waste characterization. J. Environ. Manag., 128, 661-673 (2013). https://doi.org/10.1016/j. jenvman.2013.05.063

10. Grando, R.L., de Souza Antune, M.A., da Fonseca, F.V., Sánchez, A., Barrena, R., Font, X.: Technology overview of biogas production in anaerobic digestion plants : a European evaluation of research and development. Renew. Sustain. Energy Rev. 80, 44-53 (2017). https://doi.org/10.1016/j.rser.2017.05.079
11. Di Maria, F., Sordi, A., Cirulli, G., Micale, C.: Amount of energy recoverable from an existing sludge digester with the co-digestion with fruit and vegetable waste at reduced retention time. Appl. Energy 150, 9-14 (2015). https://doi.org/10.1016/j.apene rgy.2015.01.146

12. Khoshnevisan, B., Tsapekos, P., Alvarado-Morales, M., Angelidaki, I.: Process performance and modelling of anaerobic digestion using source- sorted organic household waste. Bioresour. Technol. 247, 486-495 (2018). https://doi.org/10.1016/j.biort ech.2017.09.122

13. Pavi, S., Kramer, L.E., Gomes, L.P., Miranda, L.A.S.: Biogas production from co-digestion of organic fraction of municipal solid waste and fruit and vegetable waste. Bioresour. Technol. 228, 362-367 (2017). https://doi.org/10.1016/j.biortech.2017.01.003

14. Cesaro A., Belgiorno V., Guida M., Compost from organic solid waste : Quality assessment and European regulations for its sustainable use. Resour. Conserv. Recycl. 94, 72-79 (2015). https:// doi.org/10.1016/j.resconrec.2014.11.003

15. Myszograj, S., Kozłowska, K., Gramza, P.: Monitoring of the respiration activity of sewage sludge and biofractions of municipal waste in the composting process. Br. J. Appl. Sci. Technol. 14, 1 (2016). https://doi.org/10.9734/BJAST/2016/23153

16. Ucarogli, S., Alkan, U.: Composting of wastewater treatment sludge with different bulking agents. J. Air Waste Manag. Assoc. 66, 288-295 (2015). https://doi.org/10.1080/10962 247.2015.1131205

17. Hamoda, M.F., Abu Qdais, H.A., Newham, J.: Evaluation of municipal solid waste composting kinetics. Resour. Conserv. Recycl. 23, 209-223 (1998)

18. Fourti, O.: The maturity tests during the composting of municipal solid wastes. Resour. Conserv. Recycl. 72, 43-49 (2013). https:// doi.org/10.1016/j.resconrec.2012.12.001

19. Siemiątkowski G.: Ocena efektywności procesu mechaniczno - biologicznego przetwarzania odpadów z nawilżaniem i bez nawilżania. Pr. ICiMB. 18, 108-132 (2014).

20. Cerda, A., Artola, A., Font, X., Barrena, R., Gea, T., Sánchez, A.: Composting of food wastes: status and challenges. Bioresour. Technol. 248, 57-67 (2018). https://doi.org/10.1016/j.biort ech.2017.06.133

21. Gutiérrez, M.C., Siles, J.A., Diz, J., Chica, A.F., Martín, M.A.: Modelling of composting process of different organic waste at pilot scale : biodegradability and odor emissions. Waste Manag. 59, 48-58 (2017). https://doi.org/10.1016/j.wasman.2016.09.045

22. Onwosi, C.O., Igbokwe, V.C., Odimba, J.N., Eke, I.E., Nwankwoala, M.O., Iroh, I.N., Ezeogu, L.I.: Composting technology in waste stabilization: on the methods, challenges and future prospects. J. Environ. Manag. 190, 140-157 (2017). https://doi. org/10.1016/j.jenvman.2016.12.051

23. Waszkielis, K.M., Wronowski, R., Chlebus, W., Białobrzewski, I., Dach, J., Pilarski, K., Janczak, D.: The effect of temperature, composition and phase of the composting process on the thermal conductivity of the substrate. Ecol. Eng. 61, 354-357 (2013). https ://doi.org/10.1016/j.ecoleng.2013.09.024

24. Gutierrez, M.C., Martín, M.A., Serrano, A., Chica, A.F.: Monitoring of pile composting process of OFMSW at full scale and evaluation of odour emission impact. J. Environ. Manag. 151, 531-539 (2015). https://doi.org/10.1016/j.jenvman.2014.12.034

25. Pergola, M., Persiani, A., Palese, A.M., Di Meo, V., Pastore, V., D’Adamo, C., Celano, G.: Composting: the way for a sustainable agriculture. Appl. Soil Ecol. 123, 744-750 (2017). https://doi. org/10.1016/j.apsoil.2017.10.016

26. Sadef, Y., Gorm, T., Bester, K.: Impact of compost process conditions on organic micro pollutant degradation during full scale composting. Waste Manag. 40, 31-37 (2015). https://doi. org/10.1016/j.wasman.2015.03.003 
27. Kamaruddin, M.A., Yusoff, M.S., Aziz, H.A., Hung, Y.-T.: Sustainable treatment of landfill leachate. Appl. Water Sci. 5(2), 113-126 (2015). https://doi.org/10.1007/s13201-014-0177-7

28. Gao, J., Oloibiri, V., Chys, M., Audenaert, W., Decostere, B., He, Y., Van Langenhove, H., Demeestere, K., Van Hulle, S.W.H.: The present status of landfill leachate treatment and its development trend from a technological point of view. Rev. Environ. Sci. Biotechnol. 14, 93-122 (2015). https://doi.org/10.1007/s1115 7-014-9349-z

29. Yuan, M., Chen, Y., Tsai, J., Chang, C.: Ammonia removal from ammonia-rich wastewater. Process Saf. Environ. Prot. 102, 777785 (2016). https://doi.org/10.1016/j.psep.2016.06.021

30. Wang, D., Liu, D., Tao, L., Li, Z.: The impact on the effects of leachate concentrates recirculation for different fill age waste. J. Mater. Cycles Waste Manag. 19, 1211-1219 (2016). https://doi. org/10.1007/s10163-016-0508-x

31. Hashisho, J., El-Fadel, M.: Membrane bioreactor technology for leachate treatment at solid waste landfills. Rev. Environ. Sci. Bio/Technol. 15, 441-463 (2016). https://doi.org/10.1007/s1115 7-016-9399-5

32. Chen, P., Xie, Q., Addy, M., Zhou, W., Liu, Y., Wang, Y., Cheng, Y., Li, K., Ruan, R.: Utilization of municipal solid and liquid wastes for bioenergy and bioproducts production. Bioresour. Technol. 215, 163-172 (2016). https://doi.org/10.1016/j.biort ech.2016.02.094

33. Taddeo, R., Prajapati, S., Lepisto, R.: Optimizing ammonium removal by natural zeolite from wastewater with high loads of ammonium and solids. J. Porous Mater. 24, 1545-1554 (2017). https://doi.org/10.1007/s10934-017-0394-1

34. Peyravi, M., Jahanshahi, M., Alimoradi, M., Ganjian, E.: Old landfill leachate treatment through multistage process: membrane adsorption bioreactor and nanofitration. Bioprocess Biosyst. Eng. 39(12), 1803-1816 (2016). https://doi.org/10.1007/s0044 9-016-1655-0

35. Omar, H., Rohani, S.: Treatment of landfill waste, leachate and landfill gas: a review. Front. Chem. Sci. Eng. 9, 15-32 (2015). https://doi.org/10.1007/s11705-015-1501-y

36. Limoli, A., Langone, M., Andreottola, G.: Ammonia removal from raw manure digestate by means of a turbulent mixing stripping process. J. Environ. Manag. 176, 1-10 (2016). https://doi. org/10.1016/j.jenvman.2016.03.007

37. Liu, L., Pang, C., Wu, S., Dong, R.: Optimization and evaluation of an air-recirculated stripping for ammonia removal from the anaerobic digestate of pig manure. Process Saf. Environ. Prot. 94, 350-357 (2014). https://doi.org/10.1016/j.psep.2014.08.006

38. Brinton W.F., Evans E., Droffner M.L., Brinton R.B.: A standarized Dewar Test for evaluating of compost self-heating. Woods and Research Laboratory Report, pp. 1-16 (1992).
39. Anonim: Dewar Self-Heating Test. Instructions for use, Woods End Laboratory Inc. (2009), pp. 1-5.

40. Rice E.W., Baird R.B., Eaton A.D., Clesceri, L.S.: Standard Methods for the Examination of Water and Wastewater, 22nd ed. Alexandria, (2012)

41. Getahun, T., Nigusie, A., Entele, T., van Gerven, T., van der Bruggen, B.: Effect of turning frequencies on composting biodegradable municipal solid waste quality. Resour. Conserv. Recycl. 65, 79-84 (2012). https://doi.org/10.1016/j.resconrec.2012.05.007

42. Ogunwande, G.A., Osunade, J.A., Adekalu, K.O., Ogunjimi, L.A.O.: Nitrogen loss in chicken litter compost as affected by carbon to nitrogen ratio and turning frequency. Bioresour. Technol. 99(16), 7495-7503 (2008). https://doi.org/10.1016/j.biort ech.2008.02.020

43. Li, Z., Lu, H., Ren, L., He, L.: Experimental and modeling approaches for food waste composting: a review. Chemosphere 93, 1247-1257 (2013). https://doi.org/10.1016/j.chemospher e.2013.06.064

44. Richard, T., Hamelers, H., Veeken, A., Silva, T.: Moisture relationships in composting processes. Compost Sci. Util. 10, 1-7 (2002). https://doi.org/10.1080/1065657X.2002.10702093

45. Binner, E., Kitzberger, K.: Conditions/parameters characterizing compost process. 2003. In: Cossu, R., Diaz, L.F., Stegmann, R. (eds.) Sardinia 2003, Ninth International Waste Management and Landfill Symposium, vol. I, Margherita di Pula - Cagliari, Sardinia, Italy, 6-10 Oct 2003

46. Brinques, G., do Carmo Peralba, M., Ayub, M.: Optimization of probiotic and lactic acid production by Lactobacillus plantarum in submerged bioreactor systems. J. Ind. Microbiol. Biotechnol. 37, 1-2 (2010). doi: 10.1007/s10295-009-0665-1

47. Seruga, P., Krzywonos, M.: Screening of medium components and process parameters for sugar beet molasses vinasse decolorization By Lactobacillus plantarum using plackett-burman experimental design. Pol. J. Environ. Stud. 24, 683-688 (2015). https://doi. org/10.15244/pjoes/24931

48. Ipekoglu, N., Talinli, I.: Recovery of ammonia from human urine by stripping and absorption. Environ. Eng. Sci. 24, 5 (2007). https ://doi.org/10.1089/ees.2006.0412

49. Kang, J., Kwon, G., Nam, J.H., Kim, Y.O., Jahng, D.: Carbon dioxide stripping from anaerobic digestate of food waste using two types of aerators. Int. J. Environ. Sci. Technol. 14, 1397-1408 (2017). https://doi.org/10.1007/s13762-017-1250-1

Publisher's Note Springer Nature remains neutral with regard to jurisdictional claims in published maps and institutional affiliations. 